\title{
Lopesia davillae (Diptera, Cecidomyiidae), a new species of gall midge from Brazil associated with Davilla rugosa (Dilleniaceae)
}

\author{
V. C. Maia ${ }^{a *}$ and R. F. Monteiro ${ }^{b}$ \\ ${ }^{a}$ Museu Nacional, Quinta da Boa Vista, São Cristóvão, CEP 20940-040, Rio de Janeiro, RJ, Brazil \\ bLaboratório de Ecologia de Insetos, Departamento de Ecologia, Instituto de Biologia - IB, \\ Universidade Federal do Rio de Janeiro - UFRJ, Ilha do Fundão, CP 68020, CEP 21941-590, Rio de Janeiro, RJ, Brazil \\ *e-mail:maiavcid@acd.ufrj.br
}

Received: September 4, 2015 - Accepted: June 16, 2016 - Distributed: November 31, 2017

(With 14 figures)

\begin{abstract}
Lopesia davillae, a new species of gall midge associated with the reproductive structures of Davilla rugosa (Dilleniaceae), is described and illustrated (larva, pupa, male, female, and damage) based on material collected in Rio de Janeiro, Brazil. This new species is compared with its congeneric species. This is the first record of Lopesia on Dilleniaceae.
\end{abstract}

Keywords: gall midge, insect-plant interaction, Neotropical, taxonomy.

\section{Lopesia davillae (Diptera, Cecidomyiidae), uma nova espécie de cecidomiídeo do Brazil associada à Davilla rugosa (Dilleniaceae)}

\begin{abstract}
Resumo
Lopesia davillae, uma nova espécie de Cecidomyiidae associada a estruturas reprodutivas de Davilla rugosa (Dilleniaceae), é descrita e ilustrada (larva, pupa, macho, fêmea e dano) com base em material coletado no estado do Rio de Janeiro, Brasil. A nova espécie é comparada com as outras espécies conhecidas do mesmo gênero. Este é o primeiro registro de Lopesia em Dilleniaceae.
\end{abstract}

Palavras-chave: mosquito galhador, interação inseto-planta, neotropical, taxonomia.

\section{Introduction}

The plant family Dilleniaceae is exclusively tropical, with approximately 300 species, consisting of mainly lianas and bushes (David et al., 2006). In Brazil, seven genera have been recorded: Curatella Loefl., Davilla Vand., Dillenia L., Doliocarpus Rol. (Schultz, 1984), Neodillenia Aymard, Pinzona Mart. \& Zucc., and Tetracera L. The genus Davilla is represented in this region by 23 species (Fraga and Paula-Souza, 2015).

Davilla rugosa Poir (Dilleniaceae), often known as "cipó caboclo", is a native plant in Brazil, recorded for Brazilian northern states of Amapá, Pará and Tocantins, the northeastern states of Bahia, Maranhão and Piauí, the southeastern states of Espírito Santo, Minas Gerais, Rio de Janeiro and São Paulo, and the southern states of Paraná and Santa Catarina. It occurs in two biomes: the Amazon and Atlantic forests (Fraga and Paula-Souza, 2015). The species is used as a treatment for ulcers, elephantiasis, and swelling of the limbs, as well as an aphrodisiac and diuretic (Coimbra, 1942; Corrêa, 1984).

Two species of Cecidomyiidae have been recorded so far for this plant species. The first induces discoid leaf gall and was found in Três Marias, Minas Gerais
(Gonçalves-Alvim and Fernandes, 2001) and Porto de Trombetas, Pará (Almada and Fernandes, 2011). The second species induces imbricate bud gall and was found in São Tomé das Letras (Maia, 2013) and Serra de São José (Maia and Fernandes, 2004) (as D. brasiliana DC, synonym of D. rugosa), Minas Gerais and Mangaratiba, Rio de Janeiro (Rodrigues et al., 2014). The former species was identified at the family level, while the latter was assumed to be an unrecognized species of Asphondylia. Maia et al. (2014) recorded the occurrence of imbricate bud galls on an undetermined species of Davilla in Santa Teresa, Espírito Santo, and a third species of Cecidomyiidae (also undetermined) associated with fruits.

In the present study, we found a new species of Lopesia Rübsaamen, 1908 on D. rugosa in Teresópolis, Rio de Janeiro, in which the larva feeds freely on the reproductive structures, mainly the ovaries of developing flowers.

The genus Lopesia occurs in the Nearctic, Neotropical, Afrotropical, and Australasia regions. It presently consists of 24 species, mostly distributed in Neotropical areas (Gagné and Jaschhof, 2014; Urso-Guimarães et al., 2014). The genus has been so far associated with 12 plant 
families: Burseraceae (3 spp.), Chrysobalanaceae (2 spp.), Clusiaceae (4 spp.), Erythroxylaceae (1 sp.), Euphorbiaceae (1 sp.), Fabaceae (6 spp.), Melastomataceae (2 spp.), Myrtaceae (1 sp.), Nyctaginaceae (1 sp.), Pontederiaceae (1 sp.), Rosaceae (1 sp.), and Sapotaceae (1 sp.) (Gagné and Jaschhof, 2014). All previously known species of Lopesia are gallers, therefore, this is the first record of a free-living species.

In this study, we describe this new species of Lopesia and add Dilleniaceae as a host plant.

\section{Material and Methods}

Branches with reproductive structures of D. rugosa were collected by R.F. Monteiro in the Parque Nacional da Serra dos Órgãos (S $22^{\circ} 27^{\prime} 04^{\prime \prime}$, W $42^{\circ} 59^{\prime} 27^{\prime \prime}$ ) in April 2014, and in the Biological Reserve of Poço das Antas (22 $\left.32^{\prime} 38^{\prime \prime} \mathrm{S}, 42^{\circ} 16^{\prime} 41^{\prime \prime} \mathrm{W}\right)$ at $30 \mathrm{~m}$ altitude asl. on June 20, 2015.

The Parque Nacional da Serra dos Órgãos is situated at the central region of the State of Rio de Janeiro, in the Serra dos Órgãos massif. It includes the municipalities of Guapimirim, Magé, Petrópolis, and Teresópolis. It has approximately 20,000 hectares of Atlantic forest (ICMBio, 2015) and ranges from 300 to 2,263 $\mathrm{m}$ in altitude (Radambrasil, 1983). It comprises the highest peaks of the Serra do Mar (Drummond, 1997). The flora is diversified, with approximately 2,000 plant species recorded so far. At altitudes from 100 to $2,000 \mathrm{~m}$, the vegetation is classified as montane forest, with trees reaching $40 \mathrm{~m}$ ofheight. Above $2,000 \mathrm{~m}$, there is a predominance of grasses and species dwelling in the rocks (Drummond, 1997).

The Biological Reserve of Poço das Antas is situated in the municipality of Silva Jardim, Rio de Janeiro State and has approximately 5,000 hectares of Atlantic forest. The flora consists of approximately 365 plant species, $3 \%$ of which are vulnerable and $1 \%$ endangered, converning the conservation status (ICMBio, 2015).

Samples of the host plant were collected, pressed, and dried for preservation, later they were identified by comparison and incorporated into the herbarium of the Department of Botany, Federal University of Rio de Janeiro (record number: RFA-40632).

Branches with reproductive structures were removed from the host plant and transported in plastic bags to the laboratory, where part of the sample was dissected to obtain the larvae and part was kept in plastic pots covered with a fine screen to obtain adults and pupal exuviae. The specimens were first preserved in $70 \%$ ethanol and then mounted on microscope slides, following the Gagné (1994) methodology.

\section{Results}

Adults (males and females), pupal exuviae and larvae were obtained only from the Parque Nacional da Serra dos Órgãos, and were used to describe the new species.

Lopesia davillae Maia, sp. n. (Figures 1-14)
The new species can be included in the genus Lopesia due to the following features: (1) $\mathrm{R}_{5}$ curved at its juncture with Rs (Gagné and Marohasy, 1993); (2) R situated near the midlength of $\mathrm{R}_{1}$ (Gagné and Marohasy, 1993); (3) a short postabdomen in female, and the cercus bearing many short, sensory setae (Gagné and Marohasy, 1993), and (4) larva with short and mostly corniform terminal papillae, each on a terminal projection (Gagné and Marohasy, 1993).

Diagnosis. Adults with setulose antennal flagellomere necks in both sexes, four-segmented palpi, reduced male mid-circumfila, toothed tarsal claw, male tergites 7 and 8 , and female tergite 8 narrow, elongated, and without setae or scales. Larva with only two pairs of terminal papillae; pupa with simple antennal horn, long prothoracic spiracle, and a single row of unconnected abdominal spines.

Larva. Fusiform and cylindrical body, 5.10-6.90 mm long $(\mathrm{n}=4)$. Integument rough. Spatula (Figure 1): 0.35-0.46 mm long $(\mathrm{n}=4)$, two-toothed, apical teeth triangular, and stalk long. Two groups of three lateral papillae on each side of the spatula (two setose pairs in each group) (Figure 1). Terminal segment (Figure 2): two pairs of papillae (one shorter than the other).

Pupa. Body length: $3.90-5.30 \mathrm{~mm}(\mathrm{n}=9)$. Head (Figure 3): apical setae 0.08-0.10 mm long $(\mathrm{n}=9)$; two pairs of lower facial papillae (one asetose and the other setose), three pairs of lateral facial papillae, one setose pair, and two without seta. Prothoracic spiracle (Figure 3) elongate: $0.35-0.42 \mathrm{~mm}$ long $(\mathrm{n}=9)$, setiform, and sclerotized. Foreleg sheath slightly exceeding to the basal margin of the abdominal segment 6 , midleg sheath reaching the basal one-fifth of the abdominal segment 6 , and hindleg sheath reaching the midlength of the abdominal segment 6 . Abdominal segments 2-8 with a single row of conspicuous spines at the basal one-third, restricted to the mesal region (Figure 4).

Adult. Male: body length 4.10-4.80 $\mathrm{mm}$ long $(\mathrm{n}=8)$. Head (Figure 5): occipital process present. Eye facets circular, all closely approximated. Antenna $(n=5)$ : scape obconical 0.09-0.10 mm long, pedicel globose $0.06 \mathrm{~mm}$ long, and flagellomeres binodal and tricircumfilar; nodes, internodes, and necks setulose; basal and distal circumfila of each flagellomere with loops regular in length; reduced mid-circumfila (Figure 6); flagellomeres 1 and 2 connate; flagellomeres $1+2,0.43-0.48 \mathrm{~mm}$ long; flagellomeres 3 and 4, 0.20-0.21 mm long; flagellomere 5, 0.20-0.22 mm long; flagellomere $6,0.20-0.23 \mathrm{~mm}$ long; flagellomeres 7-9, 0.20-0.22 mm long; flagellomeres 10 and 11, 0.20-0.21 mm; and flagellomere $12,0.20-0.22 \mathrm{~mm}$ long with setulose apical process $0.05-0.07 \mathrm{~mm}$ long. Frontoclypeus with eight setae. Labrum triangular, long-attenuate, with three pairs of ventral sensory setae. Hypopharynx with anteriorly directed lateral setulae. Labella elongate-convex, each with long lateral setae and two pairs of short mesal sensory setae. Palpus $(\mathrm{n}=5)$ with four segments, all cylindrical with setae, and segment 1 shorter than the others, 0.07-0.09 mm long; segment 2, 0.11-0.13 mm long; segment 3, $0.09 \mathrm{~mm}$ long; and segment 4, 0.10-0.12 mm long. 


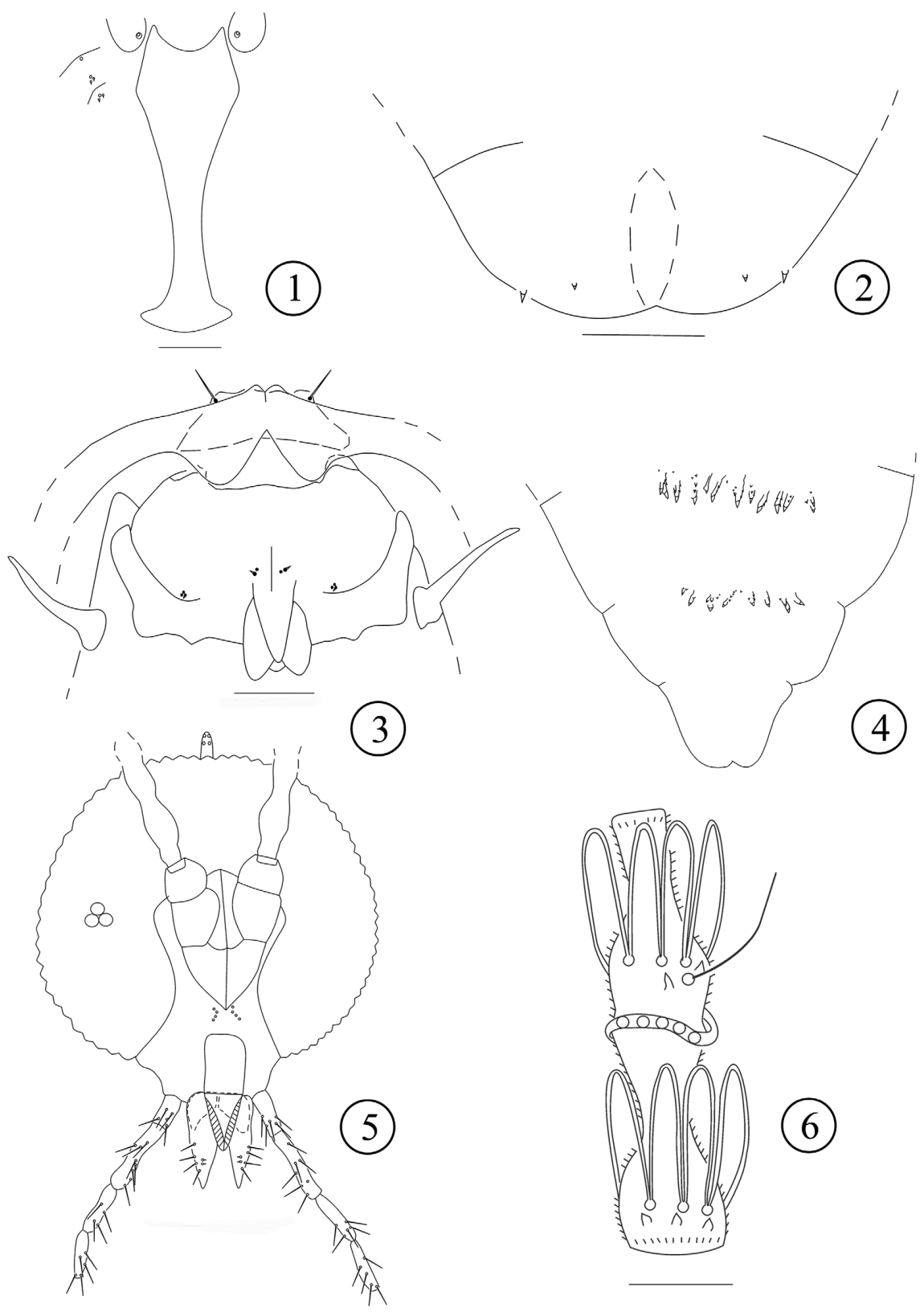

Figures 1-6. Lopesia davillae, sp. n.: (1) larva, prothoracic spatula, sternal and ventral papillae, ventral view; (2) larval terminal segment, ventral view; (3) pupa, cephalic region, frontal view, and prothoracic spiracle; and (4) pupa, last abdominal segments, dorsal view; (5) male head, frontal view; (6) male flagellomere 5.

Thorax. Wings (Figure 7) length: 3.2-3.4 mm $(\mathrm{n}=8)$. Anepisternum bare. Anepimeron with setae. Tarsal claws toothed and similar in all legs, bent near base; empodium short, reaching bent in claws (Figure 8).

Abdomen (Figure 9): tergites 1-6 sclerotized, rectangular, with a distal row of setae, few setae mesally and laterally, basal pair of trichoid sensilla, and scattered scales; tergites 7 and 8 sclerotized, elliptical, with only a basal pair of trichoid sensilla. Sternites 2-7 sclerotized, rectangular, with two rows of setae, many setae mesally, few setae laterally, basal pair of trichoid sensilla, and scattered scales; sternite 8 sclerotized, squarish, with setae from midlength to distal margin, basal pair of trichoid sensilla, and scattered scales. Terminalia (Figure 10): gonocoxite splayed, thin, setose, $0.35-0.43 \mathrm{~mm}$ long, $0.12-0.15 \mathrm{~mm}$ wide $(n=8)$, with setulose mesobasal lobe; gonostylus thin, widest and basally setulose, striated beyond basis, curved at distal one third, $0.43-0.47 \mathrm{~mm}$ long, $0.04-0.05 \mathrm{~mm}$ wide $(n=8)$; cerci apically rounded with setae and setulae; hypoproct bilobed, with setae and setulae, lobes divergent 

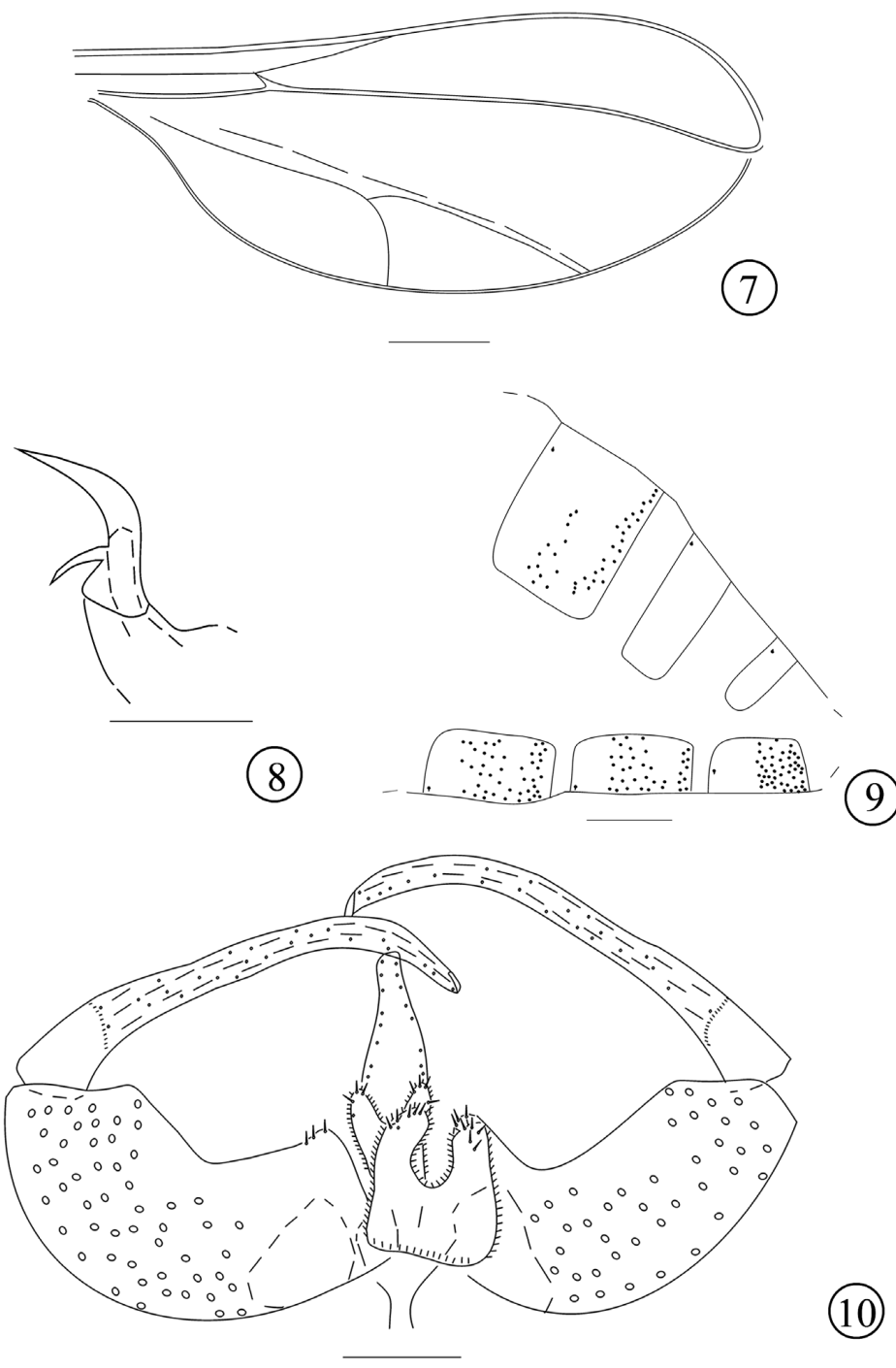

Figures 7-10. Lopesia davillae, sp. n.: (7) male wing; (8) male hindleg, tarsal claw, and empodium; (9) male abdominal segments 6-8, lateral view; and (10) male terminalia, dorsal view.

and apically rounded; cerci and hypoproct subequal in length; aedeagus long, tapered to apex, truncated apically, much longer than hypoproct.

Female: body length 4.70-5.40 mm long $(\mathrm{n}=10)$ (including ovipositor). Antenna $(\mathrm{n}=10)$ : scape obconical 0.05-0.07 mm long, pedicel globose 0.04-0.07 mm long, flagellomeres cylindrical; nodes and necks setulose; circumfila as two connected horizontal rings, sinuous (Figure 11); flagellomeres $1+2,0.44-0.47 \mathrm{~mm}$ long; flagellomere 3, $0.20 \mathrm{~mm}$ long; flagellomeres 4 and 5, 0.19-0.20 mm long; flagellomere $6,0.20-0.21 \mathrm{~mm}$ long; flagellomeres 7 and 8, 0.19-0.20 mm long; flagellomeres 9-11, $0.19 \mathrm{~mm}$ long; flagellomere 12, $0.20 \mathrm{~mm}$ long; and apical process, $0.04 \mathrm{~mm}$ long. Frontoclypeus with 10 setae. Palpus $(\mathrm{n}=10)$ : segment 1 shorter than the others, 0.06-0.10 mm long; segment 2, 0.12-0.14 mm long; segment 3, 0.09-0.10 mm long; and segment 4 0.11-0.15 mm long.
Thorax. Wings length: 3.7-4.2 $\mathrm{mm}(\mathrm{n}=9)$.

Abdomen (Figure 12): tergites 1-7 sclerotized, rectangular with a distal row of setae, few setae mesally and laterally, basal pair of trichoid sensilla, and scattered scales; tergite 8 sclerotized, narrow, elongated, with only a basal pair of trichoid sensilla. Sternites 2-7 sclerotized, rectangular, with two rows of setae, many setae mesally and laterally, basal pair of trichoid sensilla, and scattered scales, sternite 8 squarish with scattered setae and scales, and basal pair of trichoid sensilla.

Ovipositor (Figure 13) barely protrusible, female cerci separate elongate-ovoid, and setose (setae similar in length), hypoproct wide with setae and setulae.

Damage (Figure 14) and attack frequency. The females lay eggs on $D$. rugosa flowers. The larvae feed on the ovary and complete their development within the reproductive structure with the dry ovary. The development time from 

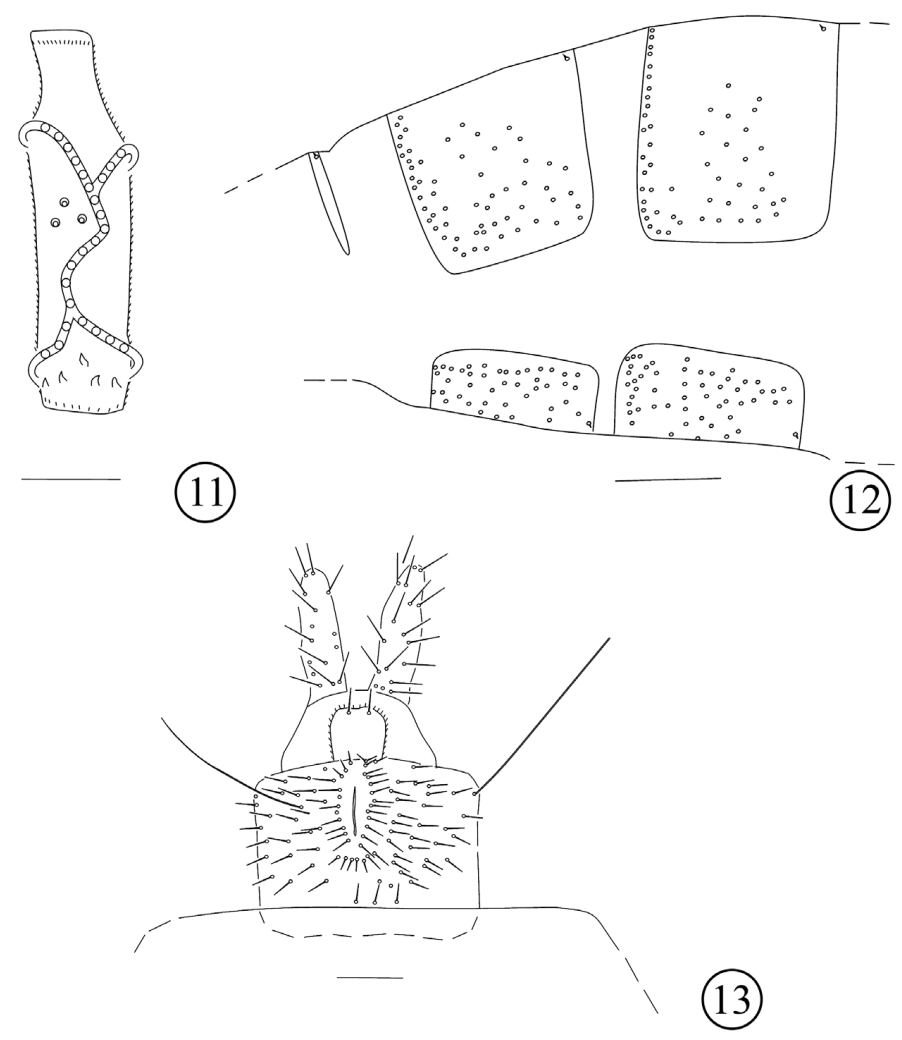

Figures 11-13. Lopesia davillae, sp. n.: (11) female flagellomere 5; (12) female abdominal segments 6-8, lateral view; and (13) ovipositor, ventral view.

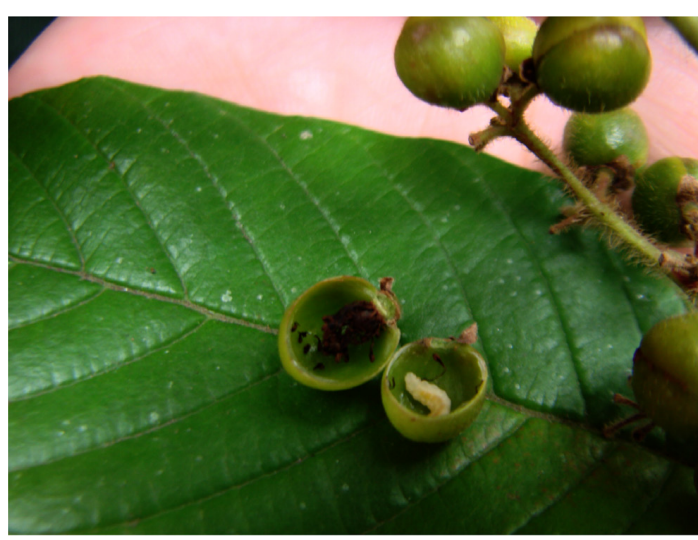

14

Figure 14. Damage on Davilla rugosa caused by Lopesia davillae, sp. n.

egg to adult emergence is at least 8 months, including larval diapause during the coldest months in PARNASO, from May to September, at $850 \mathrm{~m}$ altitude asl. Upon collection, it was impossible to state the exact development status of the reproductive structure attacked after the flower stage. Therefore, we adopted the term "reproductive structure" to refer to the unity of collection. From 30 reproductive structures sampled on June 6, 2015, in three adjacent plants, 19 had one and two had two cecidomyiid larvae, as a consequence no seeds developed. The other nine structures collected had developed seeds but no cecidomyiid larvae were found.

In the Biological Reserve of Poço das Antas, from 94 reproductive structures collected in a patch of three or four plants, 33 was attacked by cecidomyiid larvae (26 with one, six with two, and one with five larvae) and had no seeds. In 60 structures, all with seeds, no larvae were found, and in one structure, one small larva and one seed were found.

No parasitoid species, larvae or adults, were observed or obtained from D. rugosa reproductive structures from both study areas.

Etymology. The name davillae refers to the genus of the host plant.

Material examined. Holotype male. Brazil, Rio de Janeiro: Teresópolis, 22.IV.2014, Monteiro, R.F. leg., MNRJ. Paratypes, same locality, data and collector-7 males, 17 females, 10 pupal exuviae, and 4 larvae, MNRJ.

Comments. Lopesia includes adults with either bare or setulose flagellomere necks. The first condition is found in 13 of the species of the genus, while the second condition is found in 11 species. The new species has 
setulose flagellomere necks as observed in L. brasiliensis Rübsaamen, 1908, L. caulinaris Maia, 2003, L. conspicua Maia, 2003, L. elliptica Maia, 2013, L. erythroxyli Rodrigues \& Maia, 2010, L. linearis Maia, 2003, L. marginalis Maia, 2001, L. maricaensis Rodrigues \& Maia, 2010, L. similis Maia, 2004, L. simplex Maia, 2002, and L. tibouchinae Maia, 2004. Among them, seven species have male flagellomeres with basal and distal circumfila with loops and linear mid-circumfila (as in the new species), namely L. conspicua, L. eichhorniae Urso-Guimarães, 2014, L. linearis, L. marginalis, L. similis, L. simplex, and L. tibouchinae. The others have gynecoid circumfila ( $L$. caulinaris and L. elliptica), all with loops (L. erthroxyli and L. brasiliensis), or all with reduced circumfila (L. maricaensis). Among the species with basal and distal circumfila with loops and linear mid-circumfila, only L. conspicua and L. tibouchinae have female tergite 8 elliptical, as observed in the new species. However, L. conspicua has four pairs of terminal papillae (larva) and a shorter prothoracic spiracle, while the new species presents only two pairs of terminal papillae and a longer prothoracic spiracle. In addition, L. tibouchinae has three-segmented palpi (adults), bifid antennal horns, and abdominal spines connected to one another (pupa), differing from the new species, in which the palpi are four-segmented, antennal horns are simple, and dorsal spines are not connected.

The description of Lopesia davillae adds a new species to the genus, expands the host plant list to Dilleniaceae and enhances the number of species from the Atlantic Forest.

\section{Acknowledgements}

V.C.M. is grateful to the Conselho Nacional de Pesquisa e Desenvolvimento Científico (CNPq) for financial support. R.F.M. has been supported by CNPq (scholarship of productivity), INCT Hympar-sudeste (CNPq, CAPES, FAPESP), and is also grateful to ICMBio (Instituto Chico Mendes de Conservação da Biodiversidade) for the license to conduct research in the conservation units.

\section{References}

ALMADA, E.D. and FERNANDES, G.W., 2011. Insetos indutores de galhas em florestas de terra firme e em reflorestamentos com espécies nativas na Amazônia Oriental, Pará, Brasil. Boletim do Museu Paraense Emílio Goeldi. Ciências Naturais, vol. 6, no. 2, pp. 163-196.

COIMBRA, R., 1942. Notas de fitoterapia. Rio de Janeiro: Ed. Carlos da Silva Araújo. 87 p.

CORRÊA, M.P., 1984. Diccionário das Plantas Úteis do Brasil. Brasília, DF: Ministério da Agricultura, Instituto Brasileiro de Desenvolvimento Florestal. vol. II, 266 p.

DAVID, J.M., SOUZA, J.C., GUEDES, M.L.S. and DAVID, J.P., 2006. Estudo fitoquímico de Davilla rugosa: flavonóides e terpenóides. Brazilian Journal of Pharmacognosy, vol. 16, no. 1, pp. 105-108.
DRUMMOND, J.A., 1997. O Parque Nacional da Serra dos Órgãos: uma síntese da Serra do Mar. In: J.A. DRUMMOND, ed. Devastação e preservação ambiental: os parques nacionais do Estado do Rio de Janeiro. Niterói: EDUFF, pp. 183-207.

FRAGA, C.N. and PAULA-SOUZA, J., 2015 [viewed 15 May 2015]. Dilleniaceae. In: Lista de espécies da flora do Brasil. Rio de Janeiro: Jardim Botânico do Rio de Janeiro. Available from: http://floradobrasil.jbrj.gov.br/jabot/floradobrasil/FB7353

GAGNÉ, R.J., 1994. The gall midges of the Neotropical region. Ithaca: Cornell University Press. 352 p.

GAGNÉ, R.J. and JASCHHOF, M., 2014. A catalog of the Cecidomyiidae (Diptera) of the world: digital version 2. 3rd ed. Washington, DC: U.S. Department of Agriculture.

GAGNÉ, R.J. and MAROHASY, J., 1993. The gall midges (Diptera: Cecidomyiidae) of Acacia spp. (Mimosaceae) in Kenya. Insecta Mundi, vol. 7, no. 1-2, pp. 77-124.

GONÇALVES-ALVIM, S.J. and FERNANDES, G.W., 2001. Comunidades de insetos galhadores (Insecta) em diferentes fisionomias do cerrado em Minas Gerais, Brasil. Revista Brasileira de Zoologia, vol. 18, suppl. 1, pp. 289-305. http:// dx.doi.org/10.1590/S0101-81752001000500025.

INSTITUTO CHICO MENDES DE CONSERVAÇÃO DA BIODIVERSIDADE - ICMBIO, 2015 [viewed 3 September 2015]. Parque Nacional da Serra dos Órgãos. Available from: http://www.icmbio.gov.br/parnaserradosorgaos.

MAIA, V.C., 2013. Insect galls of São Tomé das Letras (MG, Brazil). Biota Neotropica, vol. 13, no. 4, pp. 164-189. http:// dx.doi.org/10.1590/S1676-06032013000400017.

MAIA, V.C. and FERNANDES, G.W., 2004. Insect galls from Serra de São José (Tiradentes, MG, Brazil). Brazilian Journal of Biology = Revista Brasileira de Biologia, vol. 64, no. 3A, pp. 423-445. PMid:15622841. http://dx.doi.org/10.1590/S151969842004000300007.

MAIA, V.C., CARDOSO, L.J.T. and BRAGA, J.M.A., 2014. Insect galls from Atlantic Forest areas of Santa Teresa, Espírito Santo, Brazil: characterization and occurrence. Boletim do Museu de Biologia Mello Leitão, vol. 33, pp. 47-129.

RADAMBRASIL, 1983. Levantamento dos recursos naturais. Rio de Janeiro: Ministério das Minas e Energia. vol. 32.

RODRIGUES, A.R. and MAIA, V.C., 2010. Duas novas espécies de Lopesia Rübsaamen (Diptera, Cecidomyiidae) do Brasil, com chave para as espécies. Biota Neotropica, vol. 10, no. 1, pp. 85-99. http://dx.doi.org/10.1590/S1676-06032010000100008.

RODRIGUES, A.R., MAIA, V.C. and COURI, M.S., 2014. Insect galls of restinga areas of Ilha da Marambaia, Rio de Janeiro, Brazil. Revista Brasileira de Entomologia, vol. 58, no. 2, pp. 173-197. http://dx.doi.org/10.1590/S0085-56262014000200010.

SCHULTZ, A., 1984. Introdução a botânica sistemática. 4. ed. Porto Alegre: Editora Universidade Federal do Rio Grande do Sul. vol. 2, 121 p.

URSO-GUIMARÃES, M.V., PELÁEZ-RODRÍGUEZ, M. and TRIVINHO-STRIXINO, S., 2014. New species of Lopesia (Diptera, Cecidomyiidae) associated with Eichhornia azurea (Pontederiaceae) from Brazil. Iheringia. Zoologia, vol. 104, no. 4, pp. 478-483. http://dx.doi.org/10.1590/1678-476620141044478483. 